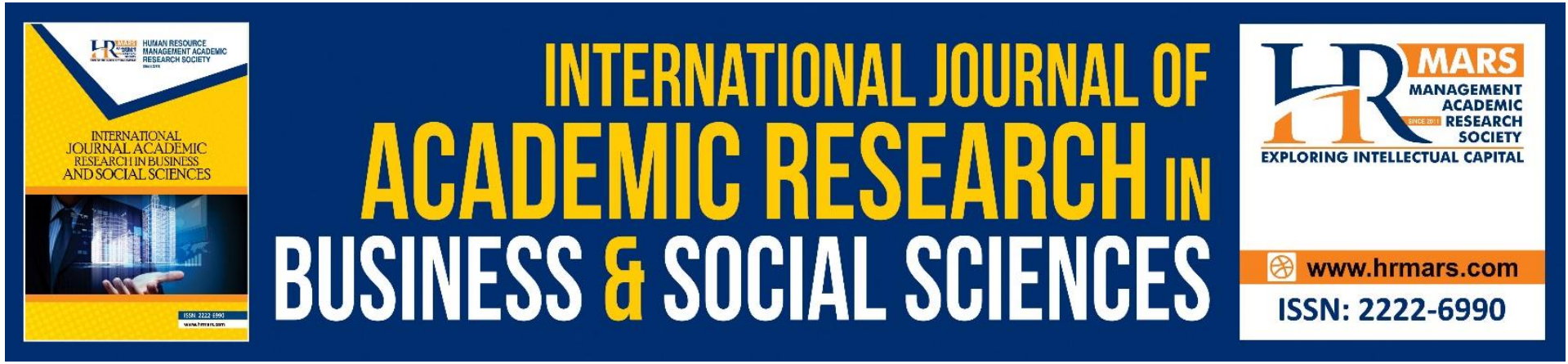

\title{
Financial Technology Awareness Among Homestay Operators in Sarawak, Malaysia
}

Kartinah Ayupp, Norizan Jaafar, Michael Tinggi

To Link this Article: http://dx.doi.org/10.6007/IJARBSS/v11-i7/10492 DOI:10.6007/IJARBSS/v11-i7/10492

Received: 17 May 2021, Revised: 19 June 2021, Accepted: 02 July 2021

Published Online: 20 July 2021

In-Text Citation: (Ayupp et al., 2021)

To Cite this Article: Ayupp, K., Jaafar, N., \& Tinggi, M. (2021). Financial Technology Awareness Among Homestay Operators in Sarawak, Malaysia. International Journal of Academic Research in Business and Social Sciences, 11(7), 497-512.

Copyright: (c) 2021 The Author(s)

Published by Human Resource Management Academic Research Society (www.hrmars.com)

This article is published under the Creative Commons Attribution (CC BY 4.0) license. Anyone may reproduce, distribute, translate and create derivative works of this article (for both commercial and non-commercial purposes), subject to full attribution to the original publication and authors. The full terms of this license may be seen

at: http://creativecommons.org/licences/by/4.0/legalcode

Vol. 11, No. 7, 2021, Pg. 497 - 512

http://hrmars.com/index.php/pages/detail/IJARBSS

JOURNAL HOMEPAGE

Full Terms \& Conditions of access and use can be found at http://hrmars.com/index.php/pages/detail/publication-ethics 


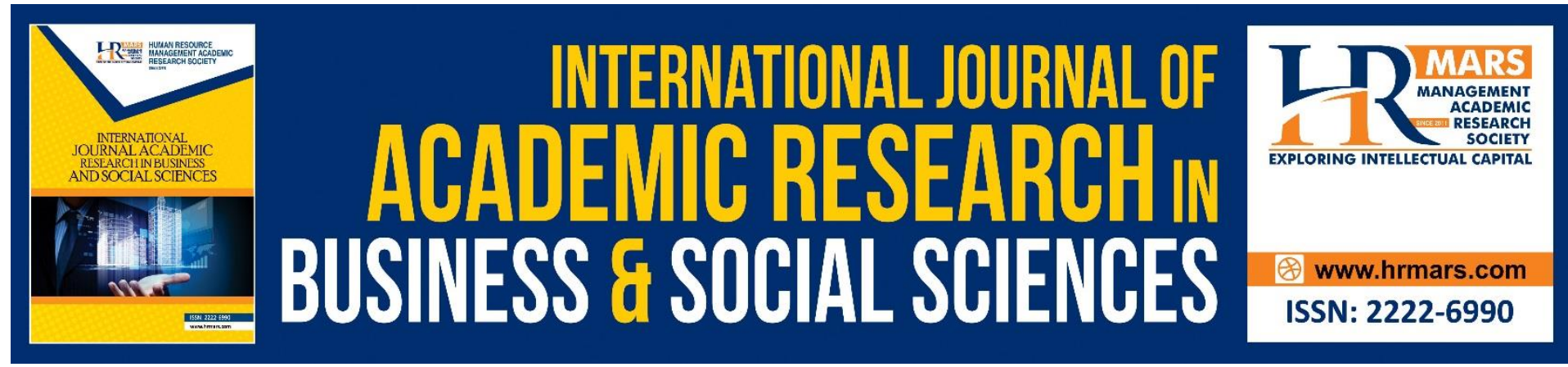

\title{
Financial Technology Awareness Among Homestay Operators in Sarawak, Malaysia
}

\author{
Kartinah Ayupp, Norizan Jaafar, Michael Tinggi \\ Faculty of Economics and Business University Malaysia Sarawak, Malaysia
}

\begin{abstract}
As a part of Malaysia's tourism landscape, the homestay business has gone through various changes in the dynamic tourism industry. It was initially developed to allow tourists and visitors to experience the social and natural heritages of the local people as they live their daily life. Just like any other business, homestay business is also being impacted by the rapid development of information and communication technology (ICT) including the disruptive development of financial technology or better known as Fintech. This is widely acknowledged as an innovative solution for financial transactions due to the great convenience that it offers not only to the consumers but also the business operators. However, as the homestay business in Malaysia tends to be operated among micro, small and medium enterprises, or to be more precise are mainly operated as personal or family businesses, the adoption of Fintech services is still at the infant stage among homestay operators. Realizing the significance of Fintech towards the development of homestay business in Malaysia, a qualitative method was adopted involving in-depth interviews of 30 homestay operators. The site of the study is in Sarawak, which is the largest state in Malaysia. An open-ended, in-depth interview method is adopted as it enables the homestay operators to give their views in a robust and detailed manner. This study is needed to identify the cause of low adoption rate among homestay operators, hence, initiating the knowledge and later actions to encourage the homestay operators to reap the benefits that the Fintech has to offer.
\end{abstract}

Keywords: Financial Technology, Homestay Operators, Awareness, Motivation.

\section{Background of Study}

The business world has been experiencing expeditious development due to the disruptive innovations in ICT. Despite the benefits it offers to the business society, rapid development in business IT also potentially poses great threats to business organizations that cannot keep abreast with the development (Dian et al., 2018). Finance is among the sectors that encounters momentous change resulting from rapid development in ICT. Financial technology, also known as Fintech, has significantly impacted the financial service industry as it has been widely adopted by business operators throughout the globe (IMF, 2019).

The emergence of these innovative technologies in recent years propelled the growth of Fintech such as artificial intelligence/machine learning, big data, robotic process automation and blockchain. Additionally, recent technologies like API platforms and user interface or 
chatbot as well as cyber security continue to enhance the efficiency of Fintech (Fintech News, 2021). The adoption of aforementioned technology enables Fintech applications to be developed in order to create more efficient financial process for consumers and industry players. Nowadays, the most common Fintech products available in the business world are mobile payment, crowdfunding, robo-advisor, insuretech and regtech (Deloitte, 2020; Kagan, 2020). Furthermore, Bank for International Settlements (BIS) in its report regarding the payment aspects in the recent era has highlighted the rise of one-stop applications that offer a wide selection of services such as e-commerce, e-hailing, food-delivery, e-payment et cetera known as the super apps, in which Grab application would be a relevant example of a super app in Malaysia (BIS, 2020). Out of the aforesaid Fintech products, improved payment and lending services have become the utmost priority by Fintech companies across the globe followed by cryptocurrency and security sectors (Varga, 2017). Deloitte (2020) report claimed that Fintech has rapidly gaining favourable acceptance by customers as compared to conventional financial and banking services as a result of greater satisfaction experienced by the customers from the easy convenience that the customers enjoyed by using Fintech services.

Consumer adoption on Fintech services in the global market has recorded a rapid growth rate since Ernst and Young first published its Global FinTech Adoption Index in 2015 by registering tremendous increase from 16\% in 2015 to 64\% in 2019 (EY, 2019). Similar sources have also indicated that money transfer and payment has emerged as the most widely utilized Fintech service by registering a remarkable adoption rate of $75 \%$ in 2019 among global consumers as compared to only $18 \%$ adoption rate in 2015 , followed by insurance services at $48 \%$ in 2019 . An identical trend can be seen in terms of the of consumer awareness of Fintech services, the same source has highlighted that global consumer recorded a high awareness rate especially on money transfer and payment service at $96 \%$, followed by insurance service at $86 \%$. Favourable acceptance and high awareness rates among consumers leads to a steady upward trend in Fintech markets. This trend is echoed in South East Asia (SEA) in which digital wallet or e-wallet has become the most rapid growth Fintech's mode of payment in the region (Wray et al., 2020).

According to Deloitte (2020) report, Asia Pacific (APAC) constitutes the largest market share in the global Fintech market and enjoying a steady growth rate since 2017. Additionally, the Asia region has registered a remarkable growth in almost all services of Fintech forcing the regulatory bodies in their respective country to take necessary measures such as regulatory sandbox to curb the risks associated with Fintech operations. For example, Malaysian government has issued regulations to supervise several Fintech services such regtech, digital lending and crowdfunding (IMF \& World Bank Group (WBG), 2019). Meanwhile, systematic actions have been introduced by the International Monetary Fund and the World Bank Group to ensure all member nations reap the advantages that development in Fintech has to offer, while simultaneously proposing measures to address risks associated with Fintech services by initiating the Bali Fintech Agenda (World Bank, 2018).

Given this development of fintech in the region, the pace of adoption in the Malaysian tourism industry is a bit slower. Although the tourism industry in Malaysia has recorded steady growth in line with the rapid development in ICT especially before Covid-19 pandemic, homestay business in Malaysia have not been quite receptive to the usage of ICT due to several 
drawbacks, such as low awareness on technological advancement as well as unfamiliarity in utilizing technology among homestay operators (Miraz et al., 2015). In Malaysia, most homestays are operated by SME owned by villagers and quite a number of unregistered homestay operators in rural areas that could not be registered due to non-compliance to certain Malaysian Homestay registration guidelines. Consequently, this makes it hard for those operators to obtain the necessary support from the Malaysian government agencies in the form of training and guidance (Ramli et al., 2020). According to Malaysian Tourism Key Performance Indicators 2018 produced by Tourism Malaysia (2019), Malaysia registered a total of 212 homestays nationwide. Out of this, 41 homestays are located in Sarawak which are run by 608 operators that generated a total revenue of RM4.03 million for these operators. Despite the low adoption of ICT among homestay operators, the number of registered homestays under Homestay Malaysia program organized by the Ministry of Tourism, Arts and Culture (MOTAC) increased to 44 homestays run by 653 operators and continue to expand to 46 homestays in 2021 in Sarawak alone (MOTAC, 2021).

In conclusion, the benefits that can be yielded from various Fintech services should be considered as significant opportunities for all business operators as it has been proven to be increasingly efficient especially due to the vast acceptance on mobile payment and money transfer among consumers around the world triggered by lower prices in mobile gadgets and telecommunication services. In addition, Fintech services should be seen as a feasible financial solution for the typical problem endured by rural-based tourism like homestays businesses. As stated by Hernandez et al. (2016), homestay operators tend to have problems in terms of critical financial resources, apart from infrastructures and accessibility sources. Homestay operators are in dire need for substantial and firm financial resources not just to keep them afloat but to enable them to enhance their business performance (Dawayan et al., 2019). Thus, adoption of Fintech services will serve as a great assistance for these homestay operators to satisfy consumers' need, hence, serves as an opportunity to increase their business capital well as their sales revenue via efficient Fintech services like e-payment and crowdfunding.

\section{Literature Review}

Before the Covid-19 pandemic hit Malaysia, the tourism industry has consistently become a major contributor to the Malaysia's GDP as it has contributed $15.9 \%$ in 2019 as compared to $15.2 \%$ in the previous year (Department of Statistics Malaysia (DoSM), 2020). The same source also indicated that the Malaysian economy had enjoyed a massive tourism receipt amounted to RM92.6 million generated from 84.7 million tourist arrivals in 2019. Meanwhile, homestay business in Malaysia holds quite an impressive share of revenue in the tourism industry by attracting 372,475 tourists that generated a total receipt worth RM27.6 million in 2018. whereby out of the total figure, Sarawak generated RM RM4.03 million from 31,487 tourists (Tourism Malaysia, 2019). Nonetheless, nation's tourism industry also has been struck by alarming number of cessations of homestays registered under Homestay Malaysia Programme due to unfavourable income generated from their operations and there are also operators that have become inactive due to the same cause (Nor \& Awang, 2017). Besides, small \& medium enterprises (SMEs) like most of the homestay operators tend to be caught with typical ineffective management of resources especially in their financial management (Morrison and Teixeira, 2004). 
Like other industries, the Malaysian tourism industry including the hospitality industry is also affected by the rapid development of ICT. Number of studies have proved that the application of ICT facilitates business operation including financial transaction, hence, has been applied comprehensively by SMEs in Malaysia (Ahmad et al., 2015; Poorangi et al., 2013). Thus, the players in tourism industry including homestay operators cannot afford to ignore the need of developing efficient ICT system that may offer great convenience to their potential consumers (Miraz, 2015). The application of ICT facilitates the adoption of smart business practices that enables convenient online services to be offered to tourists by various online tourism service providers such as Trivago and Skyscanner, as well as online payment portal such as Alipay etc. (Tsaih \& Hsu, 2018). Thus, realizing the importance of smart application of ICT in tourism industry, this study aims to examine the awareness of Fintech as part of ICT development among homestay operators in Sarawak.

\section{Homestays in Sarawak}

According to MOTAC (2019), other than homestays registered under Malaysian Homestay Program, there are number of homestays registered as SME's run by rural villagers. Malaysia's tourism industry has been experiencing a noticeable surge on the number of homestays that are operated by individuals apart from those managed by government and rural or village community, aside from a number of unregistered homestays (Ramli et al., 2020; Ramli, 2015). Undeniably, the upward growth in the number of homestays across the country is triggered by significant promotional efforts by Malaysian government on rural tourism (Muslim et al., 2017). Additionally, another main reason for increasing rural community interest to establish homestays is due to its economic benefits as it can become an attractive source of additional income (Nor \& Kayat, 2010; Muslim et al., 2017; Pusiran \& Honggen, 2013). Similar to homestay tourism in the other states in Malaysia, homestay tourism in Sarawak is classified as community-based tourism (CBT) which focus on enabling the tourists to experience the lifestyle, cultural and economic activities of the local community apart from enjoying the wonders of nature that are typically available in the Malaysian rural areas (Dawayan et al., 2019; Othman et, al. 2013; MOTAC, 2014). In Sarawak, most of the registered homestays are operated with collaboration with various stakeholders such as Sarawak Homestay Association, Sarawak Tourism and MOTAC through Tourism Malaysia as well as travel and tour companies to facilitate their business operations (Dawayan et al., 2019). Sarawak's homestays offer unique and authentic cultural and natural attractions derived from its multiethnicity and history as well as the flora and fauna (Liping et al., 2019). A study conducted by Gon et al (2016) opined that the number of tourist's arrivals to Sarawak's homestays could be influenced by previous tourists' or visitors' experience on homestays' services such as cleanliness, daily meals along with the aspects of security and availability of wonderful natural attractions. The author reiterated the assertion made by Lo et. al. (2013) that claimed that the surrounding natural environment of a particular homestay tends to be the source of appeal to attract tourists or visitors, hence, the uniqueness of the natural environment could be the driving force that motivate tourists to visit any particular longhouse-based homestays. Despite the attractive opportunity for additional income for the rural people, unfortunately homestay businesses are having a fair share of unsuccessful operators across the country (Nor \& Kayat, 2010). Furthermore, homestays in Malaysia including those that are located in Sarawak tend to be operated and managed by individuals or group of individuals (rural associations) who have been managing the homestays on a part-time basis as most of them are having other permanent professions or careers (Choy et al., 2017). Thus, this type of 
enterprise meets the typical characteristic of SME's described by Dian et al. 2018 in their study pertaining to factors influencing the adoption of e-business among homestay operators in Kuching, Sarawak. Hence, like other type of SME's that are not professionally managed, a homestay business is highly subjected to fair chance of success and failure (Mohd Nor \& Kayat, 2010). Meanwhile, Liping et. al. (2019) revealed that longhouse-based homestays are mostly run using conventional approach due to unavailability of modern management facilities in remote areas of Sarawak. Nevertheless, the authors stressed that as a part of business that made up tourism industry, homestay managers should possess professional knowledge in manging tourism business as well as tourism and event marketing in order to be successful in the tourism industry.

Rapid development of ICT in Sarawak has benefited SMEs in term of facilitating their business operations and processes including financial aspect (Omar et al., 2015). Furthermore, the same source posited that the adoption of e-business by SME's that operate homestays in Sarawak is significantly affected by organizational factors such as the size of the enterprise and the readiness of the enterprise's top management to invest on ICT. This fact confirmed the finding of a survey conducted by Chartered Practising Accountant (CPA) Australia that reported that the majority of Malaysia-based enterprises that do not have any plan to adopt to any Fintech services in the near future are comprised of small enterprises (Faridi, 2020). Sarawak's homestays, especially those that are located in remote rural areas are significantly lacking of ICT infrastructure (Dian et al., 2018; Liping et al., 2019). Realizing the importance of ICT to improve social and economic wellbeing of the people in the rural areas, Malaysian government has taken proactive actions to enhance the connectivity of rural area to the world by developing ICT infrastructures in the rural areas (Choy et al., 2017). Among the government's measures in this regard are through various programs initiated by Malaysia Digital Economy Corporation (MDEC) to close the gap between urban and rural digital accessibility such as the establishment of Digital Enhancement Centres (Banoo, 2020). Nevertheless, although the adoption of ICT in promotion activities among homestays operators in Sarawak can be considered very low. There are some glimpses of positive behaviour among a few of the operators towards the adoption of ICT for marketing purpose in the future and some have even opted to offer online payment methods to their customers as well as engaging in online booking portals (Lo et. al., 2012). The proactive measures planned by the government are expected to be a catalyst for homestay operators in Sarawak to get involved in e-commerce especially in Fintech services.

\section{The Development of Financial Technology (Fintech) in Malaysia}

Fintech is one of the innovations resulted from the rapid development of ICT. PricewaterhouseCoopers ( $\mathrm{PwC}$ ) described Fintech as an innovation resulted from strategic synergy between financial services and ICT (Loh, 2020). According to Ernst and Young's (E\&Y) Global FinTech Adoption Index in 2019, Fintech has experienced a mass growth in global adoption rate by reaching $64 \%$ as compared to only $16 \%$ in 2015 (Hwa, 2020). Consequently, along with the rapid development of ICT at the global level, Malaysia is also experiencing an increase in e-business practices among enterprises including a boom in adaptation to Fintech services. Looking at the rapid development of ICT in Malaysia, MDEC has voiced out its confidence that Malaysia has a great potential to become a digital hub for ASEAN and this confidence is also based on ASEAN Fintech census conducted by Ernst \& Young in 2018, which has labelled Malaysia as a future Asian Fintech hub (Wei, 2019). A recent survey conducted 
by CPA Australia reported that at least $75 \%$ of business organisation that based in Malaysia have adopting to at least one Fintech services such as online payment portals since recent years as a result of the strong motivation of the organizations to enhance their business operations efficiency (Faridi, 2020). This could be a result from Central Bank of Malaysia's (Bank Negara Malaysia - BNM) hard work in embracing the development of e-payment saw the introduction of the Interoperable Credit Transfer Framework which in turn triggered an increase in the number of non-bank e-money issuers through mobile applications to 47 now compared to only five in 2016 (Banoo, 2020; Moghavvemi et al., 2021). Consequently, according to International Monetary Fund (IMF, 2020), digital payment and e-wallet have become the most widely utilised Fintech's services in Malaysia which constituted a combined rate of $38.4 \%$ out of various type of Fintech services that are currently adopted by companies in Malaysia followed by other services like insurtech, lending, blockchain, crowdfunding et cetera. Moreover, IMF forecasted that Fintech in Malaysia has a promising future as a result of increasing number of middle-class people and favourable mobile and internet penetration rate across the country (Schmittmann \& Chua, 2020). Based on the statistic published by Statista (2021), Touch ' $n$ Go has turned out as the number one at $82.4 \%$ followed by Boost $(66.7 \%)$ and GrabPay (49.5\%) which established as the top three mostly used e-payment service in Malaysia in 2020. In order to portray the vastness of the financial value involved in mobile banking transactions, it has reached more than RM100 billion in 2018 generated from 6.6 million subscribers, which was a significant leap from 4.4 million subscribers in 2017 (Pikri, 2019).

In term of Fintech adoption among SME's, a survey conducted by E\&Y in 2019 on key decisionmakers at SMEs in China, the USA, the UK, South Africa and Mexico found that one out of four global SME's have adopted at least one Fintech service in their financial management (Hwa, 2020). The same survey reported that global SME's adoption rate to Fintech has reached $25 \%$ in 2019 in which out of the total figure, 56\% of the SME's have utilised banking and payment Fintech service and $46 \%$ of the SME's have used financing Fintech service. Throughout the world, Fintech services such as e-payment has not only benefited the consumers, but also contributed greatly to the development of SME's as it is considered as a safe and faster payment method that offers great convenience to customers as well as provide easement for SMEs to manage their bookkeeping, hence, creating competitive advantage from the SME's (Deloitte, 2018).

However in Malaysia, despite having numbers of assistance initiated by the government to encourage the participation of SMEs in digitalised business operation along with significant growth in Fintech industry, there are still a large number of SMEs that still opt to do conventional approach in their management of financial operations of their business (Loh, 2020). Additionally, the author reiterated that with this in mind, MDEC and BNM have collaboratively introduced the 'Fintech Booster' targeted to Fintech SMEs to enable them to understand the exact need of Fintech's end-users, hence, serves a leeway to develop an efficient Fintech services. Nonetheless, it is believed that the willingness of SME's Sarawak to adopt e-business practices including Fintech service like online payment platform is significantly affected by the degree of tolerance on risks and threats associated to the service (Ngian \& Wong, 2019). This assertion has been reiterated in a study conducted by Moghavvemi et al (2020) which also added that other significant factors that may influence merchants' adoption on e-payment such as technological compatibility, complexity, setting- 
up cost as well as the merchants' perception regarding the advantages and cost-saving that they going to gain from the adoption of e-payment.

Indeed, the significant contributions of ICT in the tourism industry has been widely recognised as it enables customer behaviour to be understood in order to fulfil customers' needs efficiently, for example the emergence of online purchasing of tourism products and services (Buhalis \& Law, 2008). Malaysia's tourism industry players should reap the opportunity provided by the government through MyDigital initiative introduced by Economy Planning Unit (EPU) of Prime Minister's Office, one aim of which is to create an inclusive digital society (EPU, 2021). In order to achieve the society as stated in MyDigital initiative, EPU has robustly promoted 'onboarding' programs to encourage enterprises and consumers to become 'cashless' society. Nowadays, tourism services such as hotel rooms, airline tickets et cetera can be easily being booked and purchased via online portals such as Trivago, Skyscanner and so on. The aforesaid online tourism services are categorized as aspects in Smart Business Ecosystem that have been practiced in Smart Tourism by players in tourism industry including homestay operators as described by Tsaih and Hsu (2018) in their study regarding artificial intelligence in Smart Tourism. The aforementioned study characterised Smart Business Ecosystem as comprising of interrelated providers such as tourism operators (e.g., homestay operators), tourism and accommodation online service providers (e.g., Trivago and TripAdvisor) as well as online payment service provider such as Alipay et cetera.

According to Mark Dubrow (2016), CEO of Onyx Center Source, an international provider of business smart solutions in hospitality industry stressed that Fintech services should be adopted in the hospitality industry as it can serve as an efficient solution for the issues related to conventional hospitality management. For example, tedious and time-consuming booking, check-in and payment transactions can be solved by using e-payment service like mobile banking and e-wallet, online accommodation booking service such as Trivago et cetera. The aforesaid notion has also been agreed by another hospitality smart managerial solution provider, MEWS (2019) which claimed that Fintech services can eliminate redundant processes that have wasted so much of guests' time at the check in desk such asking for guests' booking and credit card particulars which can be easily retrieved via the aforementioned Fintech applications. Apart from that, blockchain technology is also starting to find a place in the tourism industry as it able to provide the platform that enables direct interaction between hospitality providers and consumers, thus, enhancing the security in data and information exchange as well as eliminating intermediary costs (Fintech News Switzerland, 2019).

Inevitably, homestay operators in Sarawak will have to be a part of Fintech society as the technology continues to evolve, which might cause the latest financial technology that we using today to become obsolete, hence, might cause the traditional ways of financial transactions to become unsustainable. Recognizing the importance of Fintech to the development of homestay business, homestay operators in Sarawak need to take full advantage of opportunities provided by the government such as \#SMART Automation Grant aimed at SME's including in the tourism industry to increase participation in the digital economy not only nationally but also internationally (Banoo, 2020). Therefore, through this study, the awareness on financial technology among homestay operators in Sarawak can be identified. This study will also provide a glimpse regarding to what extent Sarawak's homestay 
operators intended to adopt Fintech service when making business decisions. Finally, the findings of this study will enable the researchers to recognise the most preferred Fintech services that the Sarawak's homestays operator which they perceived to be most effective or beneficial for their homestays. It is hoped that the findings from this study will provide an overview that will facilitate responsible parties to take the necessary measures to increase the involvement of homestay operators in Sarawak towards Fintech.

\section{Methodology}

The study adopt a qualitative research design in achieving its objective to identify the Fintech aawareness among homestay operators in Sarawak. The demographics of the sample population included 30 people, 11 males and 19 females, between the age of 30 and 65 . The majority of the homestay tourism operators in Sarawak are women with most respondents working in various occupations. Three respondents worked as government with two secondary school teachers and one was clerical staff attached in higher education institution. Three respondents operate food and groceries stall at their premises. The rest of the respondents run their homestays on a full-time basis. Most respondents demonstrated that they have limited understanding and knowledge pertaining to every aspect in the financial technology.

The age of the homestay business ranged from 3 years to 23 years old. The number of homestay rooms ranged between two to thirty rooms with the average stay at the homestay being 2 days and 1 night. The longest stay of visitors in the homestay was one week. The visitors to the homestays mainly come from United States, United Kingdom, France, Australia, Switzerland, Russia, German, Japan, Holland, Qatar, Indonesia and Singapore. All of homestay operators received visitors from different states from West Malaysia. The homestays also received visitors that worked with the government and private agencies besides students from the higher educational institutions. Despite the idea of homestay tourism being to expose visitors with the culture and lifestyle of Sarawak's people, many visitors as reported by respondents choose to stay at the homestays because of the unavailable rooms at nearby visited locations. In Malaysia, homestay tourism business has emerged as one of the alternative accommodations for many tourists and visitors to stay, instead of hotel or budget hotel. Homestay accommodations and additional services provided to the visitors are becoming an important income generation to rural communities. The yearly income received by majority of the respondents ranged from RM2,000 to RM10,000. However, a few homestays reported to receive yearly income ranged of RM20,000 until RM300,000.

\section{Findings and Discussions}

\section{How would you define your homestay's current financial strategies?}

Despite financial technology's increasing importance for business, interviews reveal that homestay operators have expressed they are hesitant to use financial technology in their business. The respondents gave various reasons for their decisions. Financial technology was given less attention as the operators do not see the importance of the technology as compared to their business core activities. According to Respondent 6, "me and my mother gave less attention on financial management in operating our homestay. Attention is focused on marketing of our homestay instead. Besides my mother has been involved in research and development on our new products which is orchid and plumeria plants as one of our main attractions here". Though the homestay operators realized the potential use of the financial 
technology in their homestay business, Respondent five claimed that "Despite I realise the benefits of financial technology in managing our financial, to implement it here is somewhat difficult due to individual factors". Respondent 4 and 7 added, "I learn from previous experience especially my homestay guests who never fulfil their promises to make payment online". The use of technology is less preferred due to the payment problem by the customers.

Unlike any other tourism businesses, homestay tourism provides a direct service to the visitors. Homestay tourism business provides accommodation and necessary services to their guests or visitors. In fact, the survival of homestay business is substantially depending on the number of homestay visitor's satisfaction which is evident from revisit to the homestays and recommendation to other visitors. Six out of thirty respondents agreed that financial technology can positively influence customer satisfaction. They have adopted online payments from guests for their homestays. For Respondent 8, "I just let my homestay guests to choose which payment is most convenience to them and they were happy with that." Respondent 2 added, "Very soon I will introduce a new financial technology called e-wallet. This is for the convenience of my homestay guests to make homestay payment online".

\section{Do homestay providers in Sarawak consider financial technology when making business decisions?}

Eleven out of thirty respondents believe that financial technology provides visitors with alternative access to traditional payment. They considered financial technology as one of the safest ways for people to protect their money. They understand that travelling visitors keeping cash in hand are exposed to many safety risks than those who don't. Respondent 24 said, "... no need to bring more cash, they can pay me through online payment". Respondent 2 emphasised the need to build customer satisfaction and customer trust to homestay business. He claimed that businesses are in advantage for adopting specific financial technology tool that could assist to effectively manage money in the account to both business owner's and guest or visitors. Good relationships between business owner and visitors are considered important for homestay businesses to adopt financial technology.

The respondents are in consensus that the decisions to adopt financial technology offers an advantage of a systematic administration of their financial activities. For example, Respondent 30 said, "financial technology provides business with a specific system or tool that can help us to manage our financials and with the use of this specific system, our financial activities can become more systematic compared to our administrative of financial using manual such as use log book." In addition, another respondent highlighted the need to adopt financial technology which has been proven as an effective tool to support homestay tourism business strategies. He said, "currently there were many business strategies supported specific technology tools, for example we have marketing grip where it specifically brings in technology application for homestay business in the context of online booking online and therefore it very important in order for homestay to become competitive to use financial technology specially to facilitate financial strategies for homestay tourism business."

When asked what reasons have prevented them from using financial technology, Respondent 7 said "I don't think that I need online money transaction as part of financial technologies development strategies for my homestay, since I have been cheated by individuals many times 
who said that they want to stay at my homestay and will do money transfer online, but the transaction never took place". Other participants experienced some frustration when asked about financial technology in general, for instance one participant replied, "I agreed that financial technology should become a platform that can alleviate individual to manage their financial effectively, in return I found this technology is difficult to master and use."

Some homestay operators indicated they their decision in adopting financial technology for their homestays were significantly influenced by the visitors. Respondent one said, "When it comes to payment, I always provide visitors with a choice, it means that they can choose the available method of payment, which is whether they want to pay for the accommodation via online or cash and which one is more convenience to them to access it, I definitely accept". The awareness to please customer is increasingly becoming an important factor for technology adoption in the tourism business.

\section{What financial technology do you think are most effective or beneficial for your homestay?}

The homestay operators indicated that they will use tools that provide service satisfaction both to homestay owners and homestay visitors. The respondents admitted that it is their priority to build a convincing image for homestay to the outside world through embracing financial technology. Respondents 10 said, "the tool that we consider in financial technology business decision is Sarawak Pay, a kind of mobile wallet and digital payment transaction under Sarawak Government Fintech Platform. Sarawak Pay could help small business like us a lot with mobile wallet and digital payment transaction that are secure, fast and convenience". In addition, respondent five said, "this kind of fintech tool not only offer visitors with a fast and convenience payment transaction but since we already recognised by tourists and visitors as a popular homestay destination in Sarawak, of course we should make our homestay more accessible to them especially in the aspect of technology such as fintech". Most visitors are believed to use electronic wallet and online payment specially to speed up the transfer of their money to another party.

Furthermore, Respondent 5 stated "the tool that we will be considered in support of this situation is Debit machine, e-wallet, Sarawak Pay and Boost Mobile Apps." Respondent 6 admitted "this is important because we were also selling our signature product to our guest namely various type of orchid plants and twin flowers. Since the concept of our homestay is homestay in garden, I believe that with this debit and credit machine, the guests can swap their debit or credit card if for instance they want to purchase one of our plants". The machine also does not incur extra cost for the homestay operators.

In order to adopt and eventually used financial technology into homestay business, several respondents interviewed indicated that they were willing to invest in financial technologies. Respondent 18, 21, 23, 24, 25 and respondent 29 informed that they were willing to invest in terms of time and money on this specific financial technology tool. Moreover, these participants identified several financial technology platforms which their found very effective to bring into their businesses and help them to manage their finances very efficiently in the future. For example, Respondent 2 said, "I already know about the Sarawak Pay and how this technology can help to boost financial aspect for homestay business, but I yet to use it. I will devote my time and show my highest effort towards it by attending courses related to Fintech. 
Respondent 25 showed attentiveness to purchase debit machine from the authorised supplier and have also considered any additional cost associated with this device. Additionally, some participants were not certain whether they could efficiently produce and dedicate constructive time and effort to educate themselves for the financial technology sites' activities. At the same time, they remained hesitant whether they would be willing to sacrifice a considerable portion of the budget to build on the knowledge and planning for financial technology.

The respondents interviewed revealed they were in a dilemma and would need to decide whether they want to adopt more specific financial technology tool for their homestays. One of the respondents mentioned, "at this time being I never think about it, I merely focus on what I have now in operating my homestay." Respondent 9 said "since financial technology is relatively new to me, I would only consider to adopt and eventually utilised this specific financial technology tool once I discovered that this specific tool brings more advantages to my homestay business than that of its disadvantages." "At this moment, I has no useful decision to give whether I want to bring this technology into my homestay business." This interview also revealed the fact that respondent also will only start to implement specific financial technology in their homestays after everybody has already use it.

\section{Conclusion}

All of the participants in the interviews recognized that their current financial strategies include a blend of computerised and non-computerised financial strategy. Though financial technology has been recognised as new strategy in managing business's financial activities, some homestay operators still use non-computerised financial tools as their primary choice in managing their business's financial activities. Homestay operators adopted financial technology to meet the demand of visitors for online payment on accommodation. To ensure the homestay operators take full control of their financial activities, some of the participants received assistance from their leaders or treasurers. There was an indication of technology influence on personal and business decisions are lacking. The majority of the homestay operators do not use online payment on their daily expenditures. Internet was not even favourable for applying for any financial loans from banks or other financial institutions.

The importance of financial technology to the homestay operators' business becomes their concern. About half of the respondents admitted that online money transaction or online banking has been one of the most effective or beneficial financial technologies for the homestay tourism business. The general consensus among the homestay operators is that online banking can alleviate online payment for homestay guests rather than using cash in making payments for the homestay accommodation. All of the homestay operators indicated that financial technology has an impact on their decisions when devising business strategies. Homestay operators are aware of the financial technology advantage to both the customers and the homestay operators.

Homestay operators in Sarawak are aware of the importance of financial technology as one of the important components to the successful performance of their homestay businesses. In addition, data on the awareness of financial technology among the homestay operators in Sarawak needs to be collected so that policy makers, educators, and the public can identify policy and development plans to help the homestay operators. To be successful in their 
homestay business, the operators must fully understand the importance of embracing technology for competitive, creative, and innovative business strategies.

This study contributes to the theoretical and practical aspects that influence the financial technology awareness and adoption among homestay operators in Sarawak. The dominant trend that has been identified to propel industry growth lies in the adoption of digitalization. Based on the findings above, it is hope that homestay business operators will be more open and motivated to embrace the innovative ways of doing business, which include the adoption of Fintech. It seems that a better understanding of the key factors affecting the adoption of financial technology among homestay operators will have implications for Malaysian homestay operators to broaden their business successfully in this global environment.

\section{Acknowledgements}

The authors acknowledge financial support from Universiti Malaysia Sarawak (UNIMAS) in funding the research presented under the FINTECH Special Grant Scheme.

\section{References}

Ahmad, S. Z., Bakar, A. R., Faziharudean, T. M., \& Zaki, K. A. (2015). An Empirical Study of Factors Affecting eCommerce Adoption among Small -and Medium Sized Enterprises in a Developing Country: Evidence from Malaysia. Information Technology for Development, 21(4), 555-572.

Bank for International Settlements (BIS). (2020). Payment Aspects of Financial Inclusion in the Fintech Era. Retrieved April 20, 2021 from https://www.bis.org/cpmi/publ/d191.pdf.

Banoo, S. (2020). The EDGE ${ }^{T M}$ Market. Overview: Making the Digital Leap. Retrieved April 15, 2021 from https://www.theedgemarkets.com/article/overview-making-digital-leap.

Buhalis, D., \& Law, R. (2008). Progress in Information Technology and Tourism Management: 20 Years on and 10 Years After the Internet: The State of eTourism Research. Tourism Management, 29(4), 609-623.

Choy, S. S. C., Atang, A., May, C. L., \& Ramayah, T. (2017). Community Perceptions on the Usage of Digital Marketing for Homestays: The Case of Ba'Kelalan, Malaysia. International Journal of Business and Society, 18(4), 775-782.

Corporate Finance Institute (CFI). (n.d.). What is Fintech (Financial Technology)? Retrieved April 20, 2021 from

https://corporatefinanceinstitute.com/resources/knowledge/finance/fintech-financialtechnology/.

Dawayan, C. R., Sondoh Jr., S. L., Tanakinjal, G. H., Nasip, S., \& Boniface, B. (2019). Homestay Resources, Marketing Capability and Hoesatay Performance: A Study Among Homestay Operators in Sabah and Sarawak. Malaysian Journal of Consumer and Family Economics, 21, 86-109.

Deliotte. (2018). SME Digital Payments: New Opportunities to Optimise. The Paytech Revolution Series 2018. Retrieved April 10, 2021 from https://www2.deloitte.com/ content/dam/Deloitte/au/ Documents/financial-services/deloitte-au-fs-sme-digitalpayments-270218.pdf.

Deloitte. (2020). Fintech: On the Brink of Further Disruption. Retrieved April 20, 2021 from https://www2.deloitte.com/content/dam/Deloitte/nl/Documents/financialservices/deloitte-nl-fsi-fintech-report-1.pdf. 
Department of Statistics Malaysia (DoSM). (2020). Tourism Satellite Account 2019. Retrieved April 26, 2021 from

https://www.dosm.gov.my/v1/index.php?r=column/cthemeByCat\&cat=111\&bul_id $=\mathrm{dEZ6NOdYUDJE}$ WkVxMzdOalY3UUJSdz09\&menu_id=TE5CRUZCblh4ZTZMODZIbmk2aWRRQT09.

Dian, R., Kasuma, J., Adenan, M. A., Nordin, J., \& Masjar, D. N. A. A. (2018). Identiying Factors of E-business Adoption among Homestay Operators in Kuching, Sarawak: Qualitative Study. Voice of Academia, 13(2), 11-22.

Dubrow, M. (2016). Onyx Center Source. Fintech Promise to Bring Hotel Payments into the Future. Retrieved April 29, 2021 from https://www.onyxcentersource.com/wpcontent/uploads/2017/ 12/FINTECH-WHITEPAPER-v5.pdf.

Economy Planning Unit (EPU) of Prime Minister's Office. (2021). Rangka Tindakan (Blueprint) Ekonomi Digital Malaysia. Retrieved April 25, 2021 from https://mdec.my/wpcontent/uploads/Rangka-Tindakan-Blueprint-Ekonomi-Digital-Malaysia.pdf.

Ernst \& Young (EY). (2019). Global FinTech Adoption Index 2019. EYGM Limited. Retrieved April 21, 2021 from https://www.ey.com/en_gl/ey-global-fintech-adoption-index.

Faridi, O. (2020). Crowdfund Insider ${ }^{\circledast}$. Over $75 \%$ of Malaysian Businesses are Now Using Fintech Products, Including Mobile Payment, Digital Wallets: Survey. Retrieved April 30, 2021 from https://www.crowdfundinsider.com/2020/08/165891-over-75ofmalaysian-businesses-are-now-using-fintech-products-including-mobile-paymentsdigital-wallet-survey/.

Fintech News. (2021). Top 5 Technologies that will Transform the Fintech Sector. Retrieved April 20, 2021 from https://fintechnews.org.top-5-technologies-that-will-transformthe-fintech-sector/.

Fintech News Switzerland. (2019). Blockchain's Promise in the Hospitality and Travel Industry. Retrieved April 30, 2021 from https://fintechnews.ch/blockchains_bitcoin/blockchainsin-the-hospitality-and-travel-industry/31843/.

Gon, G. L., Voon, B. H., \& Hamali, J. (2016). Exploring Tourist Experience of Homestays in Sarawak. In Proceedings of the 4th Borneo Research Education Conference 2016. UiTM Sarawak, Kota Samarahan, Malaysia, Aug 2016, 17-18.

Hernandez, J. M., Suarez-Vega, R., \& Jimenez, Y. S. (2016). The Inter-relationship between Rural and Mass Tourism: The Case of Catalonia, Spain. Tourism Management, 54, 4357.

Hwa, G. (2020). EY. Eight Ways FinTech Adoption Remains on the Rise. Retrieved April 18, 2021 from https://www.ey.com/en_my/financial-services/eight-ways-fintechadoption-remains-on-the-rise.

International Monetary Fund (IMF). (2020). Malaysia: A Flourishing Fintech Ecosystem. Retrieved April 13, 2021 from https: // www . imf . org? en / News / Articles / 2020 / 02 / 27 / na022820-malaysia-a-flourishing-fintech- ecosystem.

International Monetary Fund, \& World Bank Group (IMF \& WBG). (2019). Fintech: The Experience So Far. Retrieved April 20, 2021 from http://documents1.worldbank.org/curated/en/130201561082549144 /pdf/FintechThe-Experience-So-Far-Executive-Summary.pdf.

Kagan, J. (2020). Investopedia. Financial Technology - Fintech. Retrieved April 20, 2021 from https://www. investopedia.com/terms/f/fintech.asp. 
Liping, W., Mingqi, H., Zhenfeng, G., Peipei, S., Fangmei, G., \& Booho, V. (2019). China Tourists' Experiences with Longhouse Homestays in Sarawak. International Journal of Service Management and Sustainability, 4(1), 25-49.

Lo, M., Feng, R., \& Cai, L. A. (2004). Information Search Behavior and Tourist Characteristics: Internet Vis-à-vis Other Information Sources. Journal of Travel and Tourism Marketing, $17(2 / 3), 15-25$.

Loh, J. S. W. (2020). The ASEAN Post. Digitalising Malaysia's SMEs with Fintech. Retrieved April 7, 2021 from https://theaseanpost.com/article/digitalising-malaysias-smes-fintech.

MEWS. (2019). How Fintech is Disrupting Hospitality. Retrieved May 5, 2021 from https://www.mews.com/ en/blog/how-fintech-is-disrupting-hospitality.

Ministry of Tourism, Arts \& Culture (MOTAC). (2014). Malaysian Homestay Program. Retrieved April 29, 2021 from www.motac.gov.my/en/faq/141-malaysian-homestayprogramme.

Miraz, M. H., Ramli, R., Ku-Mahamud, K-R., Albarune, A. R. B., \& Islam, F. (2015). ICT Applications on Homestay Malaysia. International Journal of Science Research and Technology, 1(2), 22-31.

Moghavvemi, S., Tan, X.M., Seuk, W. P., \& Seuk, Y. P. (2021) Drivers and Barriers of Mobile Payment Adoption: Malaysian Merchants' Perspective. Journal of Retailing and Consumer Services, 59, 1-12.

Nor, M. N. A., \& Kayat, K. (2010). The Challenges of Community Based Hoestay Programme in Malaysia. In Proceedings of Regional Conference on Tourism Research: The State of the Art and its Sustainability, 66-73. Penang, Malaysia. Dec 2010, 13-14.

Morrison, A., \& Teixeira, R. (2004). Small Business Performance: A UK Tourism Sector Focus. Journal of Small Business and Enterprise Development, 11(2), 166-173.

MOTAC. (2021). Official Portal of Ministry of Tourism, Arts \& Culture Malaysia. Laporan Statistik Program Pengalaman Homestay Malaysia: Mac 2021. Retrieved April 23, 2021 from http://www.motac.gov.my/en/ download/category/11-homestay.

Muslim, H. F. M., Nurmata, S., \& Yahya, N. A. (2017). Development of Malaysian Homestay Tourism: A Review. The International Journal of Tourism Science, 10, 65-74.

Ngian, E. T., \& Wong, W. P. M. (2019). Perceived Technology Trust among Business Owners: A Study of E-business Adoption in Sarawak's SME's. Journal of Social Sciences and Humanities, 16(3), 1-12.

Nor, S. M., \& Awang, K. W. (2017). Challenges Faced by Operators to Sustain Homestay Business in Selangor, Malaysia. International Journal of Innovation in Social Sciences, 2(1), 1-11.

Omar, M., Kasuma, J., Asit, R., Achan, P., \& Mojolou, D. N. (2015). E-Business Adoption among Homestay Business: The Sarawak Experience. Advance in Business Research International Journal, 1(2), 1-9.

Othman, F., Sazali, F., \& Mohammed, B. (2013). Rural and Community Based Tourism Development in Malaysia: Prospects for Homestays as Social Economy Enterprise. TEAM Journal of Hospitality and Tourism, 10(1), 65-76.

Pikri, E. (2019). Fintech News Malaysia. How Cashless is Malaysia Right Now? Retrieved April 7, 2021 from https:// fintechnews.my/ 19964 / payments-remittance-malaysia / cashless-malaysia-credit-debit-card-e-wallet-money/2019.

Poorangi, M. M., Khin, E. W., Nikoonejad, S., \& Kardevani, A. (2013). E-commerce Adoption in Malaysia Small and Medium Enterprises Practitioner Firms: A Revisit on Rogers' Model. Anais da Acadamia Brasileira de Ciências, 85(4), 1593-1604. 
Pusiran, A. K., \& Honggen, X. (2013). Challenges and Community Development: A Case Study of Homestay in Malaysia. Asian Social Science, 9(5), 1-17.

Ramli, R. R. (2015). The Implementation and Evaluation of the Malaysian Homestay Program as a Rural and Regional Development Policy. Ph.D. Dissertation. Kobe University Repository. Retrieved April 28, 2021 from http://www.lib.kobeu.ac.jp/handle_kernel/D1006427.

Ramli, R. R., Yamazaki, J., Ibrahim, M. N., \& Safiee, L. S. (2020). Malaysian Homestays: The Need for Standardized Regulation. Built Environment Journal, 17(2), 63-74.

Schmittmann, J. M., \& Chua, H. T. (2020). Malaysia: Selected Issues. International Monetary Fund (IMF) Country Report, 20/58. Washington, D.C.: International Monetary Fund Publication Service.

Sriprasert, P., Chanin, O., \& Suttara, R. (2011). Exploring the Relationship Between Managerial Functions and the Success of Hoestay Community Based Tourism in Thailand: A Case Study of Phomlok, Nakhon Si Thammarat, Thailand. In Proceedings of the 2nd International Conference of Business \& Economics Research, 1813-1819. Langkawi, Kedah, Malaysia. Mar 2011, 14-15.

Statista. (2021). Major e-payment services used among respondents in Malaysia in 2020. Retrieved May 2, 2021 from https://www.statista.com/statistics/1106239/malaysialeading-e-payment-services/

Tourism Malaysia. (2019). Malaysia Tourism Key Performance Indicators: 2018. Retrieved April 24, 2021, from http : / / mytourismdata . tourism . gov. my / wp-content / uploads / 2019 / 10 /key - performance-indicators-2018-pdf.pdf.

Tsaih, R-H., \& Hsu, C. C. (2018). Artificial Intelligence in Smart Tourism: A Conceptual Framework. In Proceeding of the 18th International Conference on Electronic Business, 124-133. Guilin, China, December 2-6.

Varga, D. (2017). Fintech, New Era of Financial Services. Budapest Management Review, 48, 22-32.

Wei, W. M. (2019). ZICO Law. Malaysia's Potential as the Fintech Hub for the ASEAN Region. Retrieved April 18, 2021 from https://www.zicolaw.com/resources/alerts/malaysiaspotential-as-the-fintech-hub-for-the-asean-region/.

World Bank. (2018). The Bali Fintech Agenda: A Blueprint for Successfully Harnessing Fintech's Opportunities. The World Bank Press Release. Retrieved April 21, 2021 from https:// www.worldbank.org/en/news/press-release/2018/10/11/bali-fintech-agenda-ablueprint-for-successfully-harnessing-fintechs-opportunities.

Wray, P., Loh, I.,Yu, Y., Suntay, S., Han, J., \& Walker, A. (2020). Southeast Asia: Coming of the Digital Challenger Banks. Singapore Fintech Association (SFA). Retrieved April 23, 2021 from https://web-assets.bcg.com/7b/a1/b8bf356149fe91e03613750bd5d5/southeastasia-coming-of-the-digital -challenger-banks.pdf. 